\title{
Casa, família e desestruturação em Ciranda de Pedra, de Lygia Fagundes Telles
}

\author{
The Family failure in the novel Ciranda de Pedra, by Lygia Fagundes Telles
}

Suênio Campos de Lucena ${ }^{1}$

\begin{abstract}
RESUMO: Este artigo é uma proposta de análise crítica da representação familiar presente no romance Ciranda de Pedra [1954], da escritora Lygia Fagundes Telles. Nosso interesse recai em explorar vínculos parentais marcados por crises, culpas e situações trágicas que negam a ideia da família felir, perseguida pela protagonista, Virginia, busca quase sempre fadada ao fracasso, uma vez que é recorrente a impressão de personagens tentando salvar suas famílias das ameaças da fragmentação, das decadências afetiva e financeira, situação que, no caso de Ciranda de Pedra, é reforçada pelo fato de Virginia ser filha de Laura com outro homem; "fato" que acarretará em rejeição, sendo tratada como bastarda.
\end{abstract}

PALAVRAS-CHAVES: Lygia Fagundes Telles; família; rejeição; crise; Virginia

ABSTRACT: This article is a proposal of critical analysis of the familiar representation present in the novel Ciranda de Pedra [1954], by Lygia Fagundes Telles. Our interest lies in exploring parental bonds marked by crises, guilts and tragic situations that deny the idea of the happy family, something pursued by the protagonist, Virginia, search almost always doomed to failure, since it is recurrent the impression of characters trying to save their families of fragmentation, from the affective and financial decadences, a situation which, in the case of Ciranda de Pedra, is reinforced by the fact that Virginia is Laura's daughter with another man; "fact" that Patriarch Natércio and his sisters will not forgive her, rejecting her and treating her as a bastard.

KEY-WORDS: Lygia Fagundes Telles; family; crisis; rejection; Virginia.

As primeiras páginas do romance Ciranda de pedra (1954) registram uma visita da pequena Virginia, uma garota de doze anos, ao quarto de Laura, sua mãe enferma. Aos poucos, paira a sugestão de que a doença, para além das causas orgânicas, seria motivada por um castigo divino, provocada por Laura ter desonrado a própria família, ao deixar o marido, o patriarca Natércio, advogado com escritório de prestígio, as duas filhas, Bruna e Otávia (e todo o staff da família Prado - a governanta alemã Frau Herta, o motorista André etc.), e ido morar com o amante, o médico Daniel. Gradualmente, o leitor percebe porque quase nunca a loucura de Laura é nomeada, tal o grau de tabu que cerca seu ato. A sugestão é de que ela tenha enlouquecido por ter traído o marido; condenação moral que será reiterada várias vezes ao longo do romance,

\footnotetext{
1 Jornalista, escritor (Autor de 21 Escritores brasileiros; Vermelho quase Laranja, entre outros), é Professor Titular da UNEB, Universidade do Estado da Bahia. Integra o Progel, Programa de Pós-Graduação em Estudos Literários, da UEFS. É Dr. e Pós-Doutor pela FFLCH/USP. E-mail: sueniouneb@hotmail.com.
} 
inclusive, por Virginia: "Bruna disse que se minha mãe não tivesse se separado do meu pai não estava agora assim doente. Ela acha que é castigo de Deus" (TELLES, 2010, p. 20) ${ }^{2}$.

É dessa forma que o romance situa o leitor no período em que se passa, meados do século XX, ao representar o comportamento social em torno de uma família brasileira e de uma mãe que, devido a uma relação amorosa, decide se separar do marido e abrir mão da função feminina estereotipada à época, ou seja, cuidar do marido, da casa e dos filhos. Contudo, ao romper com essas atribuições, Laura não o faz de modo tranquilo, muito pelo contrário. Enfrentará toda sorte de exclusão e de rejeição social, passa por privações materiais, situação comum vividas pelas mulheres dessa época, conforme Mary Del Priore?: "A grande ameaça que pairava sobre as esposas, como já visto, eram as separações. Além do aspecto afetivo, as necessidades econômicas - a maioria das mulheres de classe média e alta dependia do provedor - e o reconhecimento social - as separadas eram malvistas" (PRIORE, 2012, p. 168). Essa "ameaça" pairava, sobretudo, porque: “A separação dos casais nos anos 50 não dissolvia os vínculos conjugais nem admitia novos casamentos. Desquitados de ambos os sexos eram vistos como má companhia, mas as mulheres sofriam mais com a situação" (PRIORE, 2012, p. 168).

Laura personifica o que acontecia com as mulheres casadas que não seguiam determinado padrão de comportamento, situação descrita por Del Priore ${ }^{4}$. Talvez por isso, o livro não exponha momentos de felicidade entre ela e o médico Daniel, como se ambos não tivessem este direito. Sobre o casal paira a "vergonha" de serem amantes e a culpa pelo desmonte da família, daí a sombra do castigo divino. Por ter se envolvido com outro homem, as consequências para Laura serão devastadoras e irreversíveis. Mãe de três filhas, ao deixar a casa do marido é julgada como mãe desnaturada que abandonon o lar. Ela e Daniel terão desfecho trágico.

Embora o contexto histórico brasileiro do período seja marcado por avanços e transformações sociais, é fato também que existe grande resistência às conquistas femininas, como o direito ao voto, aprovado em 1932, vinte anos antes do lançamento de Ciranda de pedra.

\footnotetext{
${ }^{2}$ Bruna é a filha que mais condena a mãe. Num diálogo, ela afirma para Virginia: "Nossa mãe está pagando um erro terrível, será que você não percebe? Abandonou o marido, as filhas, abandonou tudo e foi viver com outro homem. Esqueceu-se dos seus deveres, enxovalhou a honra da família, caiu em pecado mortal! Virginia quis saber o que era enxovalhar. Conteve-se" (TELLES, 2010, p. 43).

${ }^{3}$ A despeito de o romance ser desenvolvido sob o ponto de vista de Virginia, protagonista cujas ações gravitam as demais reações dessa família, vale a pena nos determos um pouco na configuração de Laura à guisa de compreensão histórica da época em que se passa a narrativa, período tratado por Mary Del Priore no livro Histórias intimas (2012) e também por Marina Maluf e Maria Lúcia Mott em "Recônditos do mundo feminino", terceiro volume da coleção $A$ História da vida privada no Brasil - República: Da Belle époque à era do rádio.

${ }^{4}$ Conforme Mary Del Priore: "As aventuras extraconjugais das mulheres eram severamente punidas. Como a honra do marido dependia do comportamento da esposa, se ela a manchasse era colocada de lado. Já a infidelidade masculina era explicada pelo comportamento 'naturalmente poligâmico' do homem" (PRIORE, 2012, p. 161). Ou seja: "As esposas dos 'anos dourados' eram valorizadas por sua capacidade de responsabilizar-se pela felicidade doméstica... Em meados do século XX, continuava-se a acreditar que ser mãe e dona de casa era o destino natural das mulheres, enquanto a iniciativa, a participação no mercado de trabalho, a força e o espírito de aventura definiriam a masculinidade" (PRIORE, 2012, p.. 161-63).
} 
Conforme Marina Maluf e Maria Lúcia Mott, o período é marcado por: "um conjunto de normas, deveres e obrigações, com seu correlato inibidor e corretivo... formalmente estabelecido para regrar o vínculo conjugal, a fim de assegurar a ordem familiar” (MALUF e MOTA, 1998, p. 379). Para as mulheres, o papel social da época é estanque e com pouca margem de contestação: "ao marido cabia prover a manutenção da família, à mulher restava a identidade social como esposa e mãe. A ele, a identidade pública; a ela, a doméstica" (MALUF e MOTA, 1998, p. 379)5.

Para Maria Rita Kehl, as mudanças realmente significativas em relação à mulher e à família só se efetivarão a partir das décadas de 1960/70, com a intensificação do movimento feminista, a chegada da pílula anticoncepcional e a aprovação da lei do Divórcio: "a independência sexual das mulheres e a possibilidade de separar a vida sexual da procriação... fizeram com que alguns conservadores e nostálgicos da ordem patriarcal atribuíssem isso... à responsabilidade pela dissolução da família" (KEHL, 2003, p. 12). Kehl' acredita que, apenas quando o século XX aproxima-se do fim é que a família que segue modelo mais "tradicional", composta por uma árvore genealógica fixa, com pai, mãe e filhos, a que ela chama de família nuclear burguesa, "excluída do convívio das ruas como garantia de preservação e transmissão dos privilégios de classe" (KEHL, 2003, p.10), dará lugar à família tentacular, núcleo marcado pela diversidade situação posterior à retratada em Ciranda de pedra.

Maluf e Mott chamam atenção para as recomendações às mulheres ${ }^{7}$ veiculadas pela imprensa da época: "a mulher sensata, principalmente se fosse casada, evitasse 'sair à rua com um homem que não seja o seu pai, o seu irmão ou o seu marido'. Caso contrário, iria expor-se à maledicência, comprometendo não só a sua honra como a do marido, conforme se lia na Revista Feminina" (MALUF e MOTT, 1998, p. 371). A mulher tinha o papel de zelar pela família como instituição a ser preservada por servir de resistência às mudanças.

\footnotetext{
${ }^{5}$ Para Mary Del Priore: "as distinções entre os papéis femininos e masculinos, entretanto, continuavam nítidas; a moral sexual diferenciada permanecia forte e o trabalho da mulher, ainda que cada vez mais comum, era cercado de preconceitos e visto como subsidiário ao trabalho do 'chefe da casa'. Se o país acompanhou à sua maneira as tendências internacionais de emancipação feminina... também foi influenciado por campanhas estrangeiras que, com o fim da guerra, passaram a pregar a volta das mulheres ao lar e aos valores tradicionais da sociedade... $\mathrm{Na}$ família, os homens tinham autoridade e poder sobre as mulheres e eram responsáveis pelo sustento da esposa e dos filhos. A mulher ideal era definida a partir dos modelos femininos tradicionais - ocupações domésticas e o cuidado dos filhos e do marido" (PRIORE, 2012, p. 160).

${ }^{6}$ Para Maria Rita Kehl: "Na segunda metade do século XX a família hierárquica, organizada em torno do poder patriarcal, começou a ceder lugar a um modelo de família onde o poder é distribuído de forma mais igualitária: entre o homem e a mulher mas também, aos poucos, entre pais e filhos... O poder do patriarca burguês é tributário da queda de figura centralizadora do monarca: é nesta transição que a família ganha importância disciplinar, de célula formadora dos cidadãos e perpetuadora das condições do poder” (KEHL, 2003, p. 11).

${ }^{7}$ É importante destacar que não se tratam de observações teóricas, mas discursos colhidos pelas estudiosas: "preocupada com mil frivolidades mundanas, passeios, chás, tangos e visitas, a mulher deserta do lar... A família se dissolve e perde a urdidura firme e ancestral dos seus liames. "Rumo à cozinha! Eis o lema do momento" (MALUF e MOTT, 1998, p. 372). O tom machista, pregado por uma publicação voltada às mulheres, é feito em forma de alerta, para que se possa reduzir "ao máximo suas atividades e aspirações, até encaixá-las no papel de ‘rainha do lar', sustentada pelo tripé mãe-esposa-dona de casa” (MALUF e MOTT, 1998, p. 373).
} 
E é assim que Ciranda de pedra acompanha as mudanças geopolíticas ocorridas no Brasil do pós-guerra, contexto social fortemente marcado pela lenta ocupação da mulher no mercado de trabalho, ocorrida devido à escassez de homens, ainda nos campos de batalha, mortos e mutilados, conforme destaca Cristina Pinto8: "A obra romanesca de Fagundes Telles reflete, a partir de Ciranda de Pedra, justamente essas mudanças, focalizando a situação da mulher numa sociedade em processo de transformação" (PINTO, 1990, p. 117). Realidade que interfere nas relações familiares representadas no romance, conforme a perseguição e a tragédia que se anuncia para Laura e Daniel, que pagam com as próprias vidas - ela, acometida pela loucura; ele, pelo suicídio. Assim, a história registra a negação da felicidade a um casal que se ama e que deve sofrer por ter destruído uma família; no caso, a oficial.

Situação que repercute diretamente no processo de formação de Virginia, personagem desenraizada e que se apresenta, desde nova, sem família, isso porque tanto o núcleo rico do Jardim Europa, onde vivem o ex-marido de Laura, Natércio, e suas irmãs, quanto o de Daniel, são ambientes hostis. Em nenhum desses lugares, ela encontra um núcleo familiar amoroso e sólido. Em ambos, há hostilidades que só aumentarão, sobretudo, após a morte de Laura, e quando descobre que Daniel, a quem Virginia chama de "tio", é seu pai biológico. Após essa revelação, o núcleo familiar abastado, os Prado, transfere para a garota a culpa antes colocada na sua mãe. Com as mortes de Laura e de Daniel, a situação se agrava ainda mais, pois, em vez de Virginia ser bem recebida pela família, o tratamento dado a ela é o de bastarda, como se ela representasse uma espécie de espelho da traição materna, ou seja, lhe condenam por ela existir e fazer com que não esqueçam o adultério da mãe.

$\mathrm{Na}$ mudança para a nova casa, a garota é obrigada a apagar os rastros e restos da casa anterior. Não pode levar nenhuma roupa ou brinquedo, devendo vestir peças usadas das irmãs: "Seu pai não quer que você venha com as suas roupas... Ela entrou no carro levando apenas a pasta da escola e a boneca de Otávia" (TELLES, 2010, p. 77), além de se submeter à rígida disciplina da Fraulein Herta: "Não encha assim o prato para depois deixar tudo, não é certo fazer isso. E descruze esse talher, ponha a faca ao lado do garfo simplesmente" (TELLES, 2010, p. 76).

Após as mortes de Laura e de Daniel, o banimento imputado ao casal se estende à Virgínia, o que a faz amargar, desde a mais tenra idade, culpa, indiferença e baixo autoestima: "'eu sou feia e ruim, ruim, ruim!” (TELLES, 2010, p. 1); “ninguém gosta de mim, ninguém! Minhas irmãs não

\footnotetext{
${ }^{8}$ Para Cristina Ferreira Pinto: "A autora, em especial na sua obra romanesca, retrata aquilo que se poderia chamar a 'decadência da família burguesa' no Brasil ou, nas palavras de Edilberto Coutinho, 'a situação difícil que a família, como instituição, atravessa" (PINTO, 1990, p. 111). Cristina Pinto ressalta que: "embora continue sendo o 'chefe' da família, o pai já não tem poder absoluto... Esse período de transformações sociais, de transição, de crise de valores, produz portanto um indivíduo - mulher e homem - também em crise ... Ciranda de Pedra, cuja primeira edição saiu em 1954, é escrito dentro desse contexto de crise" (PINTO, 1990, p. 118).
} 
se importam comigo e minha mãe só gosta de tio Daniel" (TELLES, 2010, p. 20) são as reações de alguém que, desde cedo, tem de enfrentar a rejeição familiar.

Dividida entre dois núcleos, alçada à vida adulta com problemas intrincados e acima da sua compreensão, Virginia constitui personagem de trajetória complexa, errante, ao expor uma vivência que atinge de forma negativa sua configuração de indivíduo, sobretudo, por alcançar seus anos de formação. Ela é vítima desse drama familiar, e, de alguma forma, reflete o fracasso de ambos os núcleos. Para Silviano Santiago: “O processo de inclusão de Virgínia na família será, na verdade, a forma mais terrível de aniquilamento de sua personalidade em formação" (SANTIAGO, 2010, p. 210).

O desalento de Virginia atravessa as duas partes do livro: A primeira, aos doze anos, que vai até o momento de quando perde a mãe (e Daniel) e pede a Natércio para ser colocada num internato. Ao constatar a rejeição, Virginia se matricula num colégio interno, forma de fugir da família que não a acolhe: "eu queria ficar interna... Queria morar no colégio mesmo. Posso?... Por favor, pai, eu não quero morar aqui”" (TELLES, 2010, p. 95). E a segunda, aos dezoito anos, quando deixa o colégio interno e volta a morar com as irmãs no casarão dos Prado. Em ambas as fases, assumindo parte da culpa que lhe imputam e tendo de encarar a rejeição familiar, Virginia começa a nutrir verdadeira obsessão em salvar a família, com isso tentando enquadrá-la num modelo idealizado, arranjo, consciente ou não, encontrado para se desculpar por ser filha de uma adúltera, fonte constante de angústias ao perceber a impossibilidade de seu objetivo.

A culpa da personagem aumenta ainda mais porque essa situação familiar se estende às suas relações amorosas, ao constatar que, não apenas não conseguirá reconstituir a família fragmentada de outrora, como também não poderá constituir uma nova com Conrado, o homem por quem é apaixonada.

Escrito na terceira pessoa a partir das impressões, dos desejos e desencantos de Virginia, Ciranda de pedra é considerado pela crítica um romance de formação, isso porque trata-se de narrativa que segue a trajetória de alguém desde a infância, cuja razão maior de vida parece ser salvar a própria família da desagregação, do fim.

\section{PARA A FAMÍLIA QUE EU NÃO SALVEI}

A Psicanálise enfoca algumas questões caras à família, como o lugar da criança, o estatuto da mulher e a função do pai, preocupações abordadas por Sigmund Freud em vários textos. Assim, consideramos a contribuição dessa área particularmente relevante para uma melhor compreensão do complexo sistema psíquico presente em personagens de LFT nas suas relações familiares e que poderá nos auxiliar a compreender o fracasso nas relações familiares representados nesta obra da autora. 
Num ensaio publicado em 1910, intitulado Leonardo da Vinci e uma lembrança de sua infância, Freud $^{9}$ analisa as infância e juventude do artista da Renascença italiana e, sobretudo, suas relações com a mãe, além da quase total ausência de seu pai, algo muito lamentado porque, para ele, a autoridade paterna se faz extremamente necessária na educação de um indivíduo em função da autoridade: "Na maioria dos seres humanos - tanto hoje como nos tempos primitivos - a necessidade de se apoiar numa autoridade de qualquer espécie é tão imperativa que o seu mundo se desmorona se essa autoridade é ameaçada" (FREUD, 2010, p. 152). Em suas observações sobre a arte de Da Vinci, Freud associa ausência paterna à descrença em Deus, uma vez que, para ele, o afastamento do pai provoca esfriamento na crença divina e na religião, "referências" substituídas pela figura paterna. Assim, um pai ausente acarretaria desapego a Deus e à religião. A ideia é que tal reação de desencanto por Deus seria acionada a partir da falta de autoridade e da eventual ausência do pai:

\begin{abstract}
A psicanálise tornou conhecida a íntima conexão existente entre o complexo do pai e a crença em Deus. Fez-nos ver que um Deus pessoal nada mais é, psicologicamente, do que uma exaltação do pai, e diariamente podemos observar jovens que abandonam suas crenças religiosas logo que a autoridade paterna se desmorona. Verificamos, assim, que as raízes da necessidade de religião se encontram no complexo parental (FREUD, 2010, p. 157).
\end{abstract}

O ensaio de Freud detecta algo presente em Ciranda de pedra, particularmente em diversas referências cristãs e católicas que punem a relação de Laura e Daniel de modo implacável.

Quando garotinha, Virginia lê o catecismo e ambiciona "o jardim divino que resplandecia como um sol, com anjos corados e gordos voando... flores e mais flores brotando dos canteiros" (TELLES, 2010, p. 64); costuma repetir frases e provérbios (“com Deus me deito, com Deus me levanto"; TELLES, 2010, p. 75) e tenta não julgar a mãe, mas toda hora é pressionada a fazê-lo, ao ver e ouvir reações que julgam e condenam moralmente as atitudes de Laura e Daniel, além de os associarem ao pecado, opinião partilhada pela sua irmã Bruna, que, com a morte e a doença da mãe, reitera ainda mais o discurso do castigo divino.

Diante disso, Virginia checa os pés do amante da mãe para verificar o formato das patas de um bode, reforçando uma crendice popular em torno do diabo: "O demônio toma várias formas', avisara Bruna. Cravou o olhar nos pés de Daniel. E desapontou-se, enternecida com aqueles sapatos tão humanos, já deformados pelo uso" (TELLES, 2010, p. 32). Em vez do diabo, a garota vislumbra um homem isolado e desamparado, o que reforça suas incertezas. A despeito da condenação, ela tenta compreender a atitude materna: "Tudo de melhor que ainda restava

\footnotetext{
${ }^{9}$ No ensaio O Mal-estar na civilização, Freud constata a maneira pela qual a sociedade atua reprimindo os indivíduos, no sentido de sacrificar o instinto, visando à ordem e à organização, bases de todo establishment social. Nesta legitimação, o pai teria função vital, de lei. Sua prerrogativa é separar a criança da mãe a fim de que a criança possa conduzir suas relações e perseguir seus objetos de desejo quando adulta. Contudo, a autoridade paterna só pode ser desempenhada com o aval da mãe e, assim, a lei se estabelece.
} 
tinha vindo dele. Mas se o pai lhe dera tudo, por que, meu Deus, por que então ela o deixara?” (TELLES, 2010, p.110), indaga Virginia, à cata de respostas que não vêm.

Mas uma reação sua demarca uma mudança de atitude. É quando realiza um gesto dramático, sugerindo romper com o banimento moral a que Laura e Daniel foram submetidos. Momentos antes de ir para o internato, Virgínia atira uma Bíblia pela janela e deixa o livro entre os ciprestes, gesto carregado de simbologia e que lhe marcará profundamente, provável reação ao julgamento a que seus pais foram: "Bíblia Sagrada. Reviu aqueles lábios rígidos. Se um homem dormir com a mulher de outro, ambos morrerão... Apertou o livro tentando cravar as unhas na capa. Aproximou-se da janela. E atirou-o com força na tempestade" (TELLES, 2010, p.64). Ao atirar a Bíblia, é como se Virginia buscasse extirpar os julgamentos que atingiram seus pais e ela própria, conforme destaca Silviano Santiago: "a força dominante na casa de Natércio é a Bíblia Sagrada e as leis que excluem e punem a mulher adúltera e o fruto do seu ventre" (SANTIAGO, 2010, p. 199).

Anos depois, ao retornar à mansão dos Prado, é grande o desencanto de Virginia em torno da salvação da família, uma vez que não encontrará amparo nem acolhimento. Sem fé e tendo que ainda enfrentar julgamentos morais que continuam condenando sua mãe e Daniel, resta à jovem buscar apoio em Natércio, algo que não se efetivará: “A proteção... que a religião concede a seus crentes é facilmente explicável: ela afasta o complexo paternal, do qual depende o sentimento de culpa, quer no indivíduo quer na totalidade da raça humana, resolvendo-o para ele, enquanto o incrédulo tem de resolver sozinho o seu problema” (FREUD, 2010, p. 165).

É assim que a protagonista de Ciranda de pedra não conta com forças de substituição institucionais apontadas por Freud similares à paterna, ou seja, o Estado e a Religião, instâncias não desenvolvidas no romance, daí a sua constante sensação de abandono, de exílio e de não pertencimento a algo, sobretudo, a um núcleo familiar.

Protagonista cuja trajetória é marcada pela busca de afeto e por relações estáveis que nunca se efetivam, tendo de enfrentar a indiferença e o descaso de uma família que decai, sem referências a se apegar, a trajetória de Virginia é marcada pela rejeição, somada a um crescente desencanto e vazio existencial, sensações que reverberam em sua experiência por se culpar pelo esfacelamento familiar, uma vez que é a única filha de uma relação adúltera.

Ao passo que Ciranda de pedra soa como um relato que gira em torno da improvável redenção de uma família, Virginia age desorientada, entre procurar trabalho, acompanhar o ócio das irmãs, que passam seus dias bebendo em festas e recepções, desistir de tudo e ir embora do país. Para Santiago: "O clima de desespero sentimental e de instabilidade emocional atinge os núcleos familiares burgueses da Pauliceia e tem como contrapartida, em Virgínia, um apego à indefinição sexual e à volubilidade nos afetos" (TELLES, 2010, p. 213). 
"Nada restava da sua passagem por aquela casa, nada" (TELLES, 2010, p. 159) - eis um dos sentimentos mais insistentes na obra de LFT - o de personagens diante do vazio e da inocuidade da condição humana. E assim reage Virgínia. Sem rumo definido, sem metas claras, em sua solidão e desamparo, e tendo de enfrentar a indiferença familiar, a jovem não consegue resolver desejos recalcados, pois é como se, filha adotiva de Natércio e sem a formação que as outras irmãs receberam, não pudesse se integrar aos Prado, apesar de nunca desistir da instituição familiar, embora o sentimento fatalista seja paralisante: "Que fim teria levado aquela casa?... A realidade é que o pai, a mãe, Luciana, os móveis, as roupas - tudo aquilo desaparecera como se fizesse parte de um delírio” (TELLES, 2010, p. 187) ${ }^{10}$.

Em Romances familiares, Freud afirma: "Os pais constituem para a criança pequena a autoridade única e a fonte de todos os conhecimentos. O desejo mais intenso e mais importante da criança nesses primeiros anos é igualar-se aos pais... e ser grande como seu pai e sua mãe" (FREUD, 2010, p. 153), eis um período que Virginia tenta fixar para sempre, norteando como eixo, embora essa fase seja considerada por Freud como algo inventada quando alcançamos a idade adulta, daí a insistência de alguns num tempo cercado pela ideia do paraíso perdido, "dias felizes do passado, quando o pai lhe parecia o mais nobre e o mais forte dos homens, e a mãe a mais linda e amável das mulheres" (FREUD, 2010, p. 3), o que acarretará em constante "lamento pelos dias felizes que se foram" (FREUD, 2010, p. 3), mas algo que se sabe idealizado, construído. Mesmo assim, o constante retorno à infância expõe a "supervalorização que caracteriza os primeiros anos da criança" (FREUD, 2010, p. 3).

A trajetória de Virgínia se dá a partir da agônica busca de vínculos que possam lhe oferecer afeto, segurança e proteção - elementos não encontrados na família nem tampouco em relações amorosas. A despeito de tanto ansiar por isso, suas relações familiares (com o pai Natércio; as irmãs Otávia e Bruna); domésticas (como a governanta Frau Herta) ou amorosas, como as mantidas com Conrado e Rogério, são fragmentadas e acabam não se configurando atos de afeto. Com isso, a expressão de que a personagem vaga por diferentes núcleos não é retórica. A partir da constatação de não pertencer a nenhum grupo e do fracasso de seu ideal, ela segue indecisa e desorientada, daí a sensação de passar “de mão em mão” (TELLES, 2010, p. 154).

No seu retorno ao casarão dos Prado, a família reencontrada não passa de um esboço, uma vez que está desfeita: O pai "parece um velho... A cabeça embranquecera e os ombros, antes largos, tinham agora qualquer coisa de frágil, de tímido" (TELLES, 2010, pp. 126-7), enquanto a

${ }^{10}$ Maria José Somerlate Barbosa afirma: "a fragilidade dos personagens torna-se mais presente quando Telles apresenta a focalização pela perspectiva de crianças ou jovens em seus ritos de passagem para o conhecimento tanto do amor, da amizade e da solidariedade como das perdas, dos desencontros e da descida aos labirintos emocionais" (BARBOSA, 2014, p. 44). 
antes severa governanta alemã agora agoniza doente num quarto de pensão. Enfim, a família reencontrada não se configura como tal. Trata-se de um núcleo despedaçado, cujos membros, decaídos moral e financeiramente, refletem um microcosmo hipócrita e decadente, ao expor situações permeadas pela solidão e desencanto, vide o ócio de uma elite hedonista, improdutiva e superficial, indiferente às questões do país, demonstrando uma recorrência da autora ao representar a família burguesa brasileira como instituição que não se concretiza como instância de afeto. Todo esse contexto parece só aumentar a missão redentora de Virginia; que é, também, uma forma de tentar ser aceita.

Uma passagem do romance ilustra bem essa situação, quando Virginia age à cata de afeto, de estrutura e de ordem familiares ao tentar agarrar-se aos anões de jardim afixados na entrada do casarão: "Quero entrar na roda também!, exclamou ela apertando as mãos entrelaçadas dos anões mais próximos. Desapontou-se com a resistência dos dedos de pedra. 'Não posso entrar? Não posso?', repetiu mergulhando na fonte as mãos em concha (TELLES, 2010, p. 79).

É assim que a ciranda de pedra dos anões serve de metáfora para a circunstância enfrentada pela personagem: "Já vivendo no casarão, a indiferença da família e dos amigos de suas irmãs a mantém isolada, e a resistência destes à sua integração remete ao círculo impenetrável que compõe a ciranda de anões do jardim" (COPATI, 2013, p. 65). Para Guilherme Copati, sempre que vê a ciranda de anões, a sensação da personagem é de exclusão, uma vez que não há espaço para ela na ciranda. Os anões fixos e imóveis são uma forma de: "desenredar a personagem da ciranda de pedra dos irmãos, amigos e vizinhos que a excluem e deserdam" (COPATI, 2013, p. 149). E Virgínia parece internalizar tal raciocínio, algo que só reforça sua sensação de orfandade e de desenraizamento familiar. Ao ouvir um comentário do motorista da família ("a senhora não se parece nada nem com dona Otávia nem com dona Bruna”; TELLES, 2010, p. 111), ela responde: "Não me pareço com ninguém” (TELLES, 2010, p. 111). Não se parecer com ninguém é uma forma de dizer que não possui família e de que é sozinha.

Talvez a maior decepção de Virginia ao retornar ao casarão ocorra no seu reencontro com o pai, alguém que, até então, ela esperava juntar-se em sua tentativa de agregação. Mas, em vez de configurar um aliado em sua missão, rever Natércio gera melancolia, desencanto, e, principalmente, culpa ao perceber que ela não conseguirá salvar a família. Virginia se angustia ao tentar projetar no pai um papel que ele não quer assumir, seguindo "um modelo familiar onde a figura do pai é dominante" (XAVIER, 1998, p. 47). Mas, ao contrário desse perfil, Virgínia se depara com um homem que parece ter desistido de sua vida pessoal e profissional, daí seu sentimento de culpa, como se fosse responsável pelo desajuste paterno e, de resto, de toda uma família. Uma fala da irmã Bruna sobre o pai aumenta essa sensação: "Ele está se matando, Virginia, está se matando e isso vem de longe. Nunca mais foi o mesmo homem, nunca mais 
voltou a sorrir como sorria... Você não se lembra porque isso foi antes da mamãe sair de casa para ir viver com aquele homem" (TELLES, 2010, p. 128).

Virginia se culpa por acreditar, desde criança, quando decidiu ir para um internato, que Natércio não suportou a traição de Laura e por isso se tornou um homem misantropo e fechado em si, cuja presença da filha só pioraria por não permitir que ele esqueça. Ao reencontrar um homem triste, curvado, envelhecido, vaga sombra da lei “em erosão", metáfora da crise da autoridade paterna, Virginia, agindo como se fosse a única responsável pela derrocada familiar, se amargura profundamente: "Abandonei minha mãe no momento em que ela mais precisava de mim... Mas lá tudo era feio e pobre e eu queria o conforto da casa do meu pai" (TELLES, 2010, p. 175). Culpa que tem por origem a responsabilidade pelo desmonte familiar: "Levei a inquietação para a casa onde pensei ser bem recebida, lá fui atormentar Natércio com minha presença. Ele queria esquecer e eu não deixava, eu com os olhos do outro, com o andar do outro, lembrando a traição, ressuscitando tudo" (TELLES, 2010, p. 175).

Vale ressaltar que a culpa de Virginia deve-se em grande parte à forma como é tratada por todos - um estorvo, filha ilegítima, "antagonista" da família, conforme Silviano Santiago:

\footnotetext{
No palco, o antagonismo familiar. A mãe (Laura) e a filha caçula (Virgínia) foram excluídas pelo patriarca (Natércio) e separadas das irmãs (Bruna e Otávia). Em causa, a traição de Laura com Daniel, médico da família e pai de Virgínia... A morte de Laura e o subsequente suicídio do amante garantem o retorno definitivo da caçula. A força dominante na casa de Natércio é a Bíblia Sagrada e as leis que excluem e punem a mulher adúltera e o fruto do seu ventre... O traslado de Virgínia para o casarão, bem como a morte subsequente de Laura e de Daniel, vai transformar a filha excluída em bastarda. Até então sem o saber, ela era o agente da separação na família e o distanciamento na discórdia. A bastarda se encaminha para a condição de intrusa na casa de Natércio. Ela foi e volta a ser o pivô do antagonismo (SANTIAGO, 2010, p. 208).
}

Essas referências que consideram Virgínia ponto de discórdia, elemento desagregador e deflagrador da cisão familiar a impulsionam a perseguir a ideia de uma família harmônica. A culpa se soma à mágoa de não receber afeto de Natércio desde pequena; misto de sentimentos que a entristecem profundamente quando lembra das ocasiões em que esperou por um afago e um gesto de afeto, que nunca vieram: "quantas vezes, quantas! - detivera-se ansiosa, à espera de uma palavra, um gesto. Ah! Como era importante para ela o mais ligeiro sinal de afeição. Mas sempre encontrou a porta fechada. Não seria agora que ele iria lembrar-se de abri-la... Não se aproxime muito, parecia advertir-lhe com o orgulho de animal ferido. "Não se aproxime tanto" (TELLES, 2010, p. 127).

O pai ausente é um tema caro ao primeiro romance da autora, uma vez que Virginia terá sua trajetória marcada "por essa ausência do pai, isto é, pela desestruturação familiar; e daí, decorrem... os conflitos das personagens. Seus romances têm protagonistas mulheres, vivendo crises de identidade, determinadas, em sua maioria, pelas relações familiares" (XAVIER, 1998, p. 
44). Observação feita por Cristina Ferreira Pinto: “em Fagundes Telles a descentralização da figura do Pai revela-se especialmente através de uma abordagem narrativa que privilegia protagonista e co-protagonistas femininas" (PINTO, 1990, p. 119); e que seria marca da autora: "Em seus três primeiros romances o ponto de vista narrativo principal pertence à mulher e enfoca relações dentro das quais o homem já não tem poder dominante” (PINTO, 1990, p. 119). Enquanto que em Verão no aquário e As Meninas o pai está ausente dos acontecimentos, "em Ciranda de Pedra ele é uma figura que vai se apagando com o desenrolar da narrativa... o Pai deixa de ser o eixo central do romance" (PINTO, 1990, pp. 119-20).

Mas, ao seguir o percurso movediço de Virginia, o leitor pode perceber que ela segue sua trajetória como se estivesse num labirinto, imagem cunhada por Maria Somerlate Barbosa, cuja ideia de círculo dá título ao livro, a ciranda, e que bem define o desejo da personagem por avançar - metáfora que representa sua existência circular, espécie de sina que lhe tira qualquer possibilidade de redenção justamente para quem tanto demanda amor, conforme Guilherme Copati: "Virginia vive no limiar do espaço privado, errando entre os vivos e os mortos, lutando por autorreconhecimento e por aceitação" (COPATI, 2013, p. 150).

O sofrimento de Virginia se deve à constatação de que, apesar de ter vivido em dois núcleos distintos, sequer chegou a pertencer a um deles. Mas não é o que ocorre. Um exemplo ilustra bem essa sua condição. Ao chegar ao casarão dos Prado, ela não é esperada pela família, conforme ressalta o motorista: "Acho que ainda nem sabem que a senhora chegou" (TELLES, 2010, p. 113). É como se todos fugissem da sua presença e não desejassem reintegrá-la à família.

Essa situação de não pertencer a algo talvez seja a imagem mais dramática retratada em Ciranda de pedra, uma vez que esta situação não se restringe apenas ao microcosmo das relações familiares, mas é reveladora da condição geral da protagonista, cujo percurso é marcadamente vago, errante, solitário e sem orientação. Até a sua paixão mesmo que vaga por Conrado não seguirá adiante quando descobre que este é impotente, ironia maior que a impede de constituir uma nova família. Sem lar e sem família, após fracassar em sua missão, resta à protagonista ir embora do país.

Uma vez que a trajetória de Virginia é permeada pelo desejo de ter uma casa, lugar atribuído ao afeto e à proteção, mas que se revelará hostil, cabe tratarmos com mais ênfase desse dado a fim de compreendermos o fracasso da sua empreitada.

\section{A CASA: ESPAÇO DE AFETO E HOSTILIDADE}

A casa é o lugar por excelência da família, onde ocorrem encontros, mas também onde se desenrolam desavenças, embates, revelações bombásticas, rupturas - situações passadas em ambientes outrora abastados e que, no presente, se encontram em processo de decadência. É dessa forma que as casas nos escritos de LFT quase sempre se encontram decaídas, com fissuras 
físicas que espelham as crises nos relacionamentos dos moradores, como se a instituição familiar ruisse lenta e conjuntamente com o espaço doméstico. Se repararmos, a literatura de LFT com frequência se refere ao microcosmo da casa, associando-o a um espaço familiar que decai e soçobra, refletindo com isso as relações familiares.

O espaço da casa é decisivo para compreendermos a trajetória angustiante e movediça em que se debate a protagonista de Ciranda de pedra. Mais precisamente, não é uma, mas são duas casas frequentadas por Virginia à cata de realizar o seu ideal da família feliz: A casa simples do médico Daniel, onde agoniza sua mãe Laura, e o casarão de Natércio. Virginia é obrigada a encarar esta condição cindida entre dois lugares, já que não consegue se fixar em nenhum deles, conforme Mabel Knust Pedra: "Seu sentimento de exclusão é permanente, o que lhe traz a certeza de ser a passageira clandestina que, flutuando desde criança entre dois espaços, não pertence a qualquer um deles" (PEDRA, 2013, p. 62).

$\mathrm{Na}$ primeira parte do romance, tendo como tarefa escolar a "descrição de uma família" (TELLES, 2010, p. 30), a garota se divide sobre qual casa deve escrever: a pequena casa do "tio" Daniel e da sua mãe Laura, ou a mansão abastada dos Prado, marcada pela opulência? Ao responder o exercício, a "solução" encontrada pela garota é instalar a mãe na casa de Natércio: "Minha família, repetiu baixinho... Boa ideia! E ponho minha mãe morando lá também, faz de conta que nada mudou, que é como antes" (TELLES, 2010, p. 32), tentativa de resolver algo maior, ou seja, o impasse familiar a que se vê submetida: Uma casa abastada, rica, e a outra, onde se encontra a mãe agonizante e o pai que se passa por tio e cujo ambiente é pobre, triste, desolador. Angustiada por essa tensão, a menina oscila entre esses dois lugares, mas em nenhum encontrará sua ansiada familia feliæ. Tanto a mansão dos Prado quanto a casa onde vive com a mãe são espaços que, em vez de a acolherem, rejeitam-na, daí sua angústia.

Vale destacar que o modelo da família feliz que Virgínia persegue tem também um componente de classe social. Desde criança, ela sofre com as limitações impostas na casa onde vive com Daniel e a mãe ("ele disse que ia me dar uma mobília azul e não me deu nada"; TELLES, 2010, p. 17), em detrimento do luxo e da riqueza da casa de Natércio, descritos com deslumbramento: "Que casa! Na semana passada ele trocou o automóvel por um novo, todo preto, com almofada vermelha, uma beleza... Eles vivem tão bem, têm tanta coisa! Bruna disse que meu pai está ficando cada vez mais rico e que é o maior advogado que existe" (TELLES, 2010, p. 25).

Quando garota, no momento de escrever a redação escolar, Virgínia demonstra que o seu ideal de familia passa pela posse de bens materiais, uma vez que, para ela, uma família deve ser bem sucedida financeiramente: 
'Descrição de uma família', Virgínia escreveu no alto da página... Podia escrever sobre um homem do campo voltando para casa, a enxada no ombro, contente porque sabe que à sua espera estão a mulher e os filhinhos. Na realidade, o homem devia ser esfarrapado e sujo, cercado de crianças barrigudas e piolhentas, mais encardidas do que um tatu... Mas não usava escrever sobre gente assim, nas composições todos tinham que ser educados e limpos (TELLES, 2010, p. 30).

Um perfil que destoa da casa de Daniel, mas que também não encontra acolbida na casa de Natércio porque, apesar de abastada, Virgínia relata reiteradas vezes a aspereza das relações, a rigidez da governanta e a indiferença das irmãs. É assim que a personagem lamenta não ter uma casa, a despeito de frequentar duas.

Um estudo específico em torno da questão foi feito por Elódia Xavier ${ }^{11}$ que, em $A$ Casa na fiçãa de autoria feminina (2012), analisou como várias ficcionistas brasileiras têm representado o espaço da casa em suas obras. Na obra de LFT, Xavier chama atenção para a frequência com que aparece a casa da infância. Para a estudiosa, a casa da infância trata-se de categoria estilística, expediente de que a autora se vale para suas personagens lamentarem a passagem inexorável do tempo, a mudança abrupta dos costumes, a constatação daquilo que foi e não volta mais, o esquecimento das pessoas, a efemeridade das coisas, a inevitabilidade da morte. Contudo, além de se referir de forma breve à obra de LFT, a análise de Xavier contempla apenas o romance Verão no aquário (1963), livro seguinte à Ciranda de pedra.

Virgínia é mais uma das personagens de LFT que não se conformam diante do esquecimento das coisas e dos sujeitos. O avançar das horas é lamentado como algo que apaga, destrói e aniquila os ambientes, as relações familiares e até as lembranças mais intensas. É assim que a passagem do tempo é sempre vista como algo prejudicial, negativo, que atinge as pessoas de forma devastadora e até alcança a memória, provocando o esquecimento do que passou. Contudo, a lembrança de um tempo supostamente feliz falha porque, em sua fase adulta, ela vê que se trata de tempo morto, findo, que nunca existiu, daí o desejo constante de se apegar a um período associado à harmonia e à felicidade familiares.

Em diversos momentos, Virgínia se divide entre as duas casas onde morou: a de Laura e Daniel, mais humana e afetiva; e a outra, rica e descrita com glamour, mas avessa ao afeto. $\mathrm{Na}$ primeira, ela se sente acolhida, mas se angustia diante da doença da mãe e das limitações financeiras. Na segunda, perdura o sentimento da rejeição e da hostilidade. Porém, na segunda parte do livro, na fase adulta, diante de situações permeadas pelo desencanto, as descrições de

\footnotetext{
${ }^{11}$ No livro A casa na ficção de autoria feminina, Elódia Xavier aborda o espaço doméstico elaborado nas literaturas de LFT, Lya Luft, Rachel de Queiroz, Clarice Lispector, Ondina Ferreira, Myriam Campello, Tatiana Salem Levy, dentre outras. Para Xavier, a casa é "o espaço da família, o lar... que dá segurança e proteção" (XAVIER, 2012, p. 41).
} 
ambas parecem se aproximar. Tanto a casa de Natércio quanto a de Daniel ${ }^{12}$ são vistas como espaços carregados de tristeza, sem afeto e união (componentes que enxerga para a formação da ideia da família feliz) isso porque seus membros têm dificuldades de comunicação e parecem desinteressados em estabelecer um pacto familiar.

As descrições do casarão seguem a mesma ordem das descrições familiares, isto é, nelas, há a apreensão de uma família que se deixa corromper, hedonista, fechada em si, perfil oposto ao descrito no passado, quando o casarão chegou a ser descrito como lugar de felicidade. No presente, os ambientes narrados refletem a decadência física dos espaços, extensiva às relações familiares: "Nos móveis, no tapete puído, nos livros, parecia haver uma poeira muito fina, quase imperceptível de tão fina, mas suficiente para dar a tudo uma embaçada atmosfera de abandono" (TELLES, 2010, p. 57). O ambiente reencontrado passa então a ser descrito como sujo, decaído, depauperado, similar ao que aconteceu à família Prado: "Ali estava o casarão cinzento, esparramado em meio do gramado. Notou que os quatro ciprestes tinham desaparecido... No centro da roda, a fonte. Não podia ver o filete d'água... débil mas constante por entre as pedras cobertas de musgo" (TELLES, 2010, p. 113).

Ao expor sinais de decadência, o casarão de Natércio revela uma família que se desintegra e que seria metáfora da casa em ruínas. E assim segue a descrição da fonte, quando lamenta o que passou e não pode mais ser recuperado: "Virgínia aproximou-se do caramanchão. Nunca lhe parecera tão agreste como naquele instante... Há muito tempo ninguém mais entrava ali. A mesa apresentava sinais de apodrecimento e os tufos de avencas estavam definitivamente secos" (TELLES, 2010, p. 192).

Uma resposta de Virgínia à amiga Letícia deflagra o quanto a casa ${ }^{13}$ é, para ela, índice do lugar da família, espaço que lamenta nunca ter tido. Para ela, não ter uma casa é não pertencer a uma família: "Virgínia, mais uma vez repito o convite, por que não vem morar comigo? Sei que você não está bem lá, o seu pai não consegue se esquecer que... Bem, a gente sabe que sua casa não é

\footnotetext{
12 Para Letícia Malard, as casas de Natércio e de Daniel são: "dois mundos opostos, cujo eixo é Virginia. Esses espaços, apesar de coexistirem na realidade apenas até a metade da narrativa, coexistem sempre na imaginação e nas recordações da moça. Ela está dividida entre eles devido a laços familiares e afetivos... Virginia não se ajusta aos espaços que lhe são reservados, buscando transgredi-los por um mecanismo de fuga - viajar para longe, sem tempo marcado para a volta. Dessa maneira, pretende libertar-se" (MALARD, 1981, p. 191).

${ }^{13}$ Segundo Mabel Pedra: as casas em LFT são "índices de confinamento" (PEDRA, 2013, p. 81): “A representação das casas de Lygia... revela o enclausuramento existencial das personagens - operando ainda a casa como símbolo de confinamento e desagregação entre os membros da família" (PEDRA, 2013, p. 80). Com isso, a trajetória da protagonista: "vai ser marcada, portanto, por um desajuste que tem dupla origem: a desagregação de sua família... e a sua inadaptação aos dois círculos por onde transita (o de Natércio e o de Laura e Daniel)" (PEDRA, 2013, p. 59). Ou seja: "O desenraizamento de Virgínia pode ser pensado, assim, em termos de transitoriedade e impessoalidade... sem fixar-se em nenhum deles, sem efetivamente enraizar-se para poder realizar-se com plenitude" (PEDRA, 2013, p. 59). Segundo Guilherme Copati, essa impressão repercute em Virginia, marcada pela rejeição, algo que a faz manterse sempre em trânsito: "a família que rejeitara, e que se mostra a sua verdadeira família, desintegrou-se sob a insígnia da loucura, da morte, do suicídio e dos segredos. Virgínia descobre-se completamente órfã, sem um destino que a ampare" (COPATI, 2013, p. 68).
} 
aquela" (TELLES, 2010, p. 149). No que Virgínia responde: "Nenhuma é minha casa" (TELLES, 2010, p. 149). Ou seja, sem casa, a impressão de Virgínia é de que nunca teve família.

Já na fase adulta, Virgínia constata a ilusão deslumbrada de quando descreveu o casarão de Natércio, relacionando seu ideal de felicidade a status, dinheiro e luxo. Nada disso terá importância na sua fase adulta, ao contrário. O pouco que restou da infância é insignificante para marcá-la como sujeito protegida pelo afeto, reiterando a constatação frequente em torno do apagamento das coisas e das pessoas, como a severa governanta alemã, já substituída por outra empregada: “Ao passar pelo armário do vestíbulo, encontrou-o com as portas abertas... Ali Frau Herta guardava o velho chapéu de feltro azul-marinho. Nada restava da sua passagem por aquela casa, nada" (TELLES, 2010, p. 159). Virginia se angustia ao perceber que pessoas como Frau Herta, sua mãe e Daniel não são mais lembrados nem sequer citados nas rodas de conversas. Esquecimento que também se estende a seu pai, com quem ela não consegue estabelecer vínculo.

A crítica tem dado particular atenção à questão familiar ao associá-la ao espaço doméstico, apontando-o como ambiente produtor de sentidos e de referências imprescindíveis para a constituição de um indivíduo em sua sociedade. E, no caso de Ciranda de pedra, o(s) ambiente(s) $\mathrm{da}(\mathrm{s})$ casa(s) se sobressai/em para além do espaço físico do romance e revela(m) a subjetividade na construção do perfil oscilante de Virgínia, pois, para ela, o espaço físico é: "indicador de exclusão, já que o que caracteriza seu percurso existencial é um contínuo deslocamento que se configura como uma errância no círculo familiar... A constante inadequação... a torna invariavelmente estranha nas casas" (PEDRA, 2013, pp. 62-3).

Virginia, desenraizada por completo, desiste de se fixar a uma casa, após constatar a dificuldade de concretizar a família idealizada. Virginia encara o fracasso da família feliz, renuncia a sua missão, inclusive de ela própria constituir uma família (ao lado de Conrado), e resolve realizar uma viagem de navio sem rumo: "uma longa viagem, sem passagem de volta, pelo menos por enquanto" (TELLES, 2010, p. 189). Decisão que significa desistência em relação à família: "Tomarei um navio e irei por aí com um mínimo de bagagem, com um mínimo de planos ou sem plano algum...” (TELLES, 2010, p. 199).

A partida de Virginia em pleno réveillon - data marcada pela união de amigos e familiares sem ninguém para se despedir, expõe o nível de solidão, de exclusão e de isolamento a que está submetida, situação que ela parece se dar conta quando finalmente nomeia e encara a impotência do homem amado, Conrado. Eis algumas questões extraídas por nós em torno do tema da família no romance Ciranda de pedra. 


\section{REFERÊNCIAS}

BARBOSA, Maria José Somerlate. "Labirintos, redemoinhos e sorvedouros nos contos de Lygia Fagundes Telles" in: Arquivos femininos: Literatura, valores, sentidos. Florianópolis: Mulheres, 2014. COPATI, Guilherme. “A errância e o gótico em Ciranda de pedra. In: GOMES, Carlos Magno. Interdisciplinar - Especial 90 anos Lygia Fagundes Telles. Aracaju: UFS, 2013.

DAVID, Pierre. Psicanálise e família. Lisboa: Moraes Editores, 1977.

DOR, Joel. O pai e sua função em Psicanálise. São Paulo: Jorge Zahar, 1991.

FREUD, Sigmund. A interpretação dos sonhos (1910). Rio de Janeiro: Imago, 1991. . Cinco lições de psicanálise, Leonardo da Vinci e outros trabalhos (1910). São Paulo: Imago, 2010. . Moisés e o monoteísmo. São Paulo: Imago, 1999.

. Observacõoes sobre um caso de neurose obsessiva (1909 - 1910). São Paulo: Imago, 2001. . O caso de Schreber: artigos sobre técnica e outros trabalhos (1911 - 1913). Rio de Janeiro: Imago, 1990.

. O ego e o id e outros trabalhos. Rio de Janeiro: Imago, 1989. . O mal estar na civilização (1930). São Paulo: Imago, 1996. . Sobre a psicopatologia da vida cotidiana. Rio de Janeiro: Imago, 1987.

KEHL, Maria Rita. Em defesa da família tentacular. In: PIRES, Paulo Roberto. Outros 500. Rio de Janeiro: Aeroplano, 2003.

LUCENA, Suênio Campos de. Esquecimento e lembrança em Lygia Fagundes Telles. 2008. 132 p. Tese (Doutorado em Teoria Literária e Literatura Comparada) - Faculdade de Filosofia, Letras e Ciências Humanas, Universidade de São Paulo, São Paulo.

(Org.). Lygia Fagundes Telles - entre ritos e memórias. Aracaju: Criação Editora, 2013.

MALARD, Letícia. Escritos de Literatura Brasileira. Rio de Janeiro: Comunicação, 1981.

MALUF, Marina e MOTT, Maria Lúcia. Recônditos do mundo feminino. In: NOVAIS, Fernando e SEVCENKO, Nicolau (Org.). História da vida privada no Brasil - República: Da Belle époque à era do rádio (Vol. 3). São Paulo: Companhia das Letras, 1998.

PEDRA, Mabel Knust. Sombras silenciosas - Estranheza e solidão em Lygia Fagundes Telles e Edward Hopper. Niteroi: Eduff, 2013.

PINTO, Cristina Ferreira. O Bildungsroman feminino. São Paulo: Perspectiva, 1990.

PRIORE, Mary Del. Histórias intimas. São Paulo: Planeta, 2012.

ROUDINESCO, Elizabeth. A família em desordem. Rio de Janeiro: Zahar, 2008.

SANTIAGO, Silviano. O Avesso da festa. In: Ciranda de Pedra. São Paulo: Companhia das Letras, 2010.

TELLES, Lygia Fagundes. Ciranda de pedra. São Paulo: Companhia das Letras, 2011. 
Verão no aquário. São Paulo: Companhia das Letras, 2011.

TIETZMAN, Vera Maria. Dispersos e inéditos - Estudos sobre Lygia Fagundes Telles. Goiânia: Cânone Editorial, 2009.

XAVIER, Elódia. Declínio do patriarcado. Rio de Janeiro: Record, 1998. 